\title{
ROLA KOBIET UKRAIŃSKICH W WYDARZENIACH REWOLUCYJNYCH NA PRZELOMIE 2013-2014 ROKU
}

\author{
THE ROLE OF UKRAINIAN WOMEN IN \\ REVOLUTIONARY EVENTS AT THE TURN OF 2014
}

\begin{abstract}
The article explains the notion of European revolution, Revolution of Dignity, Revolution of the Fire, Euromaidan. There is also an analysis of women participation in the events that took place at the turn of 2014, as well as examples of various kinds of initiatives which appeared during the revolutionary events in Ukraine.
\end{abstract}

Key words: European revolution in Ukraine; Revolution of Dignity; Revolution of the Fire; women; activists; Beregynya

\section{STRESZCZENIE}

Artykuł wyjaśnia takie pojęcia jak: Rewolucja Europejska, Rewolucja Godności, Rewolucja Ognia, Euromaidan. Analizie poddano również udział kobiet w wydarzeniach, które miały miejsce na przełomie lat 2013-2014, a także przykłady różnego rodzaju inicjatyw, które pojawiły się w czasie rewolucyjnych wydarzeń na Ukrainie.

Słowa kluczowe: Europejska Rewolucja na Ukrainie; Rewolucja Godności; Rewolucja Ognia; kobiety; aktywistki; Beregynia

This is an Open Access article distributed under the terms of the Creative Commons Attribution 3.0 PL License (creativecommons.org/licenses/by/3.0/pl/), which permits redistribution, commercial and non-commercial, provided that the article is properly cited. (C) The Author(s) 2014.

Publisher: Institute of Slavic Studies PAS [Wydawca: Instytut Slawistyki PAN] 
K oniec 2013 roku na Ukrainie był pełen różnego rodzaju wydarzeń, których bieg trudno było przedwidzieć. Odmowa ówczesnego prezydenta W. Janukowycza podpisania Porozumienia o Stowarzyszeniu z Unią Europejską doprowadziła do pojawienia się protestów na Majdanie Niepodległości w Kijowie ${ }^{1}$. Pocztątkowo były to pokojowe manifestacje, głównie studentów. W społeczeństwie ukraińskim manifestacje były różnie odbierane. Część społeczeństwa zaangażowała się od początku, część dołączyła do protestów znacznie później, część nie opowiedziała się po stronie manifestacji, byli też tacy, dla których te wydarzenia były obojętne.Wydarzenia końca 2013 i początku 2014 roku najczęściej są określane mianem Europejskiej Rewolucji, jak też Rewolucji Godności lub Rewolucji Ognia oraz EuroMajdanem. Nazwy tych wydarzeń są używane zamiennie. Uważam, że każde z tych określeń jest właściwe i we właściwy sposób opisuje wydarzenia z tamtego okresu.

O Europejskiej Rewolucji możemy mówić tylko w kontekście pierwszych dni protestów, wtedy też miały one jeszcze charakter pokojowy. Uważam, że to określenie możemy odnieść do okresu, zanim doszło do pierwszej próby spacyfikowania protestów przez siły milicji w nocy z 30 listopada na 1 grudnia 2013 roku. Głównym hasłem Europejskiej Rewolucji było: „Ukraina - to Europa!" Studenci wzywali władze ukraińskie do opowiedzenia się za wartościami europejskimi - sprawiedliwością, pokojem, wysoką kulturą osobistą, tolerancją, równością, różnorodnością i poszanowaniem praw człowieka („Wartości europejskie", b.d.). Charakterystycznymi symbolami pojawiającymi się w czasie tych protestów były symbole Ukrainy i Unii Europejskiej.

Po pierwszych nieudanych próbach stłumienia protestów, do haseł proeuropejskich dołączyło hasło „Бандy-zemь!” Od tego momentu możemy mówić o początku Rewolucji Godności. Ta rewolucja trwała najdłużej i można się pokusić o stwierdzenie, że trwa ona nadal, mimo iż reżim Janukowycza został obalony. W przeciwieństwie do pojęcia Europejskiej Rewolucji, które nie wymagało większego tłumaczenia, na pojęciu Rewolucja Godności warto skupić uwagę. Godność według słownika języka polskiego to „poczucie własnej wartości i szacunek dla samego siebie" („Godność", 2014). Pojęcie godności pojawia się w porządkach konstytucyjnych państw respektujących zasadę praworządności oraz w prawie międzynarodowym. W Konstytucji Polski w preambule stwierdza się istnienie przyrodzonej godności człowieka, a art. 30 Konstytucji RP charakteryzuje ją jako "przyrodzone, niezbywalne i nienaruszalne źródło wolności i praw człowieka i obywatela” („Konstytucja Rzeczypospolitej Polskiej z dnia 2 kwietnia 1997 r.," 1997). W Konstytucji Ukrainy godność jest jednym z kluczowych pojęć. O godności jest mowa w art. 3, 21, 28, 41, 68, 105 Konstytucji. Uznaje ona godność za jedną z "najwyższych wartości społecznych" na Ukrainie (art. 3), oświadcza, że „wszyscy ludzie są wolni i równi w swej godności i swych prawach” oraz że „każdy ma prawo do poszanowanie jego godności”(„Конституція України", 1996).

Na Majdanie Niepodległości każdy na swój sposób interpretował pojęcie godności. A. Hohołkin, na portalu Українська правда. Життя, w odniesieniu do wydarzeń mających miejsce na Majdanie napisał: „Wiem, czym jest godność, widziałem ją”. Swoją myśl kontynuuje on w artykule pt. „Rewolucja Godności: mamy pamiętać”, w którym podkreśla, że wydarzenia na przełomie 2013-2014 roku na Ukranie nie były konfrontacją pomię-

Majdan Niepodległości (укр. Майдан Незалежності) - jest to największy plac w centrum Kijowa, gdzie odbywają się najważniejsze wydarzenia. 
dzy wschodem i zachodem, pomiędzy Rosją i Ukrainą, były one konfrontacją pomiędzy tymi, którzy mają godność i tymi, którzy jej nie mają lub nie rozumieją czym jest godność. Dalej opisuje on momenty, w których widział godność - w oczach kobiet, które wysyłały swoich mężów, ojców, synów na Majdan, widział ją w lekarzach - wolontariuszach, którzy z ognia wynosili rannych, w młodych ludziach, którzy bez kasków i kamizelek kuloodpornych bronili barykady tylko z drewnianymi kijami w ręku. Godność była wypisana na twarzach osób, które w 20-stopniowym mrozie leżaly na ośnieżonych schodach budynku Prokuratury Generalnej na znak protestu przeciwko łamaniu praw człowieka. Godność była w ludziach, którzy mimo zimna i problemów z dotarciem na Majdan, z powodu zamknięcia metra, przywozili żywność i środki medyczne na Majdan i do szpitali. Godność była także w ukraińskich Ultras, czyli pseudokibicach, których zachowanie na meczach budziło wiele zastrzeżeń, ale gdy nad krajem zawisło niebezpieczeństwo, zjednoczyli się i stali ramię w ramię na Majdanie, biorąc aktywny udział w Rewolucji Godności. Ludźmi godności można nazwać dziennikarzy, którzy mimo narażenia na niebezpieczeństwo własnego życia filmowali najbardziej tragiczne wydarzenia we współczesnych dziejach Ukrainy. Ludźmi godności stali się także Krymscy Tatarzy, którzy udostępnili duchownym Ukraińskiej Prawosławnej Cerkwi Kijowskiego Patriarchatu swoje meczety, aby w nich mogli oni odprawiać mszę świętą oraz którzy brali aktywny udzał w Rewolucji Godności („Революція гідності: ми маємо пам'ятати”, b.d.).

Rewolucja Ognia była najbardziej krwawym i tragicznym okresem we współczesnej historii Ukrainy. Miała ona miejsce po świętach Bożego Narodzenia, gdy po pewnym świątecznym uspokojeniu, sytuacja na Ukrainie zawrzała z nową siłą. W dniu 16 stycznia 2014 roku zostały w brutalny i niekonstytucyjny sposób przegłosowane w Radzie Najwyższej Ukrainy ustawy, które sprowadzały Ukrainę na drogę dyktatury. Podpisanie ustaw przez prezydenta doprowadziło do wybuchu społecznych protestów. Mocą nowych ustaw został wprowadzony zakaz poruszania się na drogach publicznych w kolumnach składających się z ponad pięciu pojazdów bez wcześniejszego uzyskania pozwolenia ze strony milicji. Oznaczało to, że od 16 stycznia weselnicy poruszający się w orszaku weselnym, składającym się z więcej jak pięciu pojazdów mogli spotkać się z poważnymi sankcjami, jak pozbawienie prawa jazdy i samochodu na dwa lata. Ustawy ograniczały wolność słowa i zgromadzeń, umożliwiały wydawanie wyroków zaocznych przez sądy oraz ułatwiały pozbawienie deputowanych immunitetu („Ukraina: "dyktatorskie ustawy" ekspresowo wchodzą w życie", b.d.). Protestanci wyruszyli do budynku Rady Najwyższej Ukrainy, aby wyrazić niezadowolenie z podjętych działań Parlamentu, jednak zanim dotarli do gmachu, spotkali się z oddziałami milicji "Berkut” na ulicy Hruszewskiego, gdzie doszło do starć, W trakcie których użyto różnych rodzajów broni („Сутички після Народного Віча у Києві", b.d.). Protesty trwały przez kolejne dni. 22 stycznia 2014 roku Rewolucja zebrała krwawe żniwo, pojawiły się pierwsze ofiary wśród manifestujących. Taki obrót sytuacji doprowadził do nasilenia protestów i pojawienia się na Majdanie Niepodległości osób, które dotychczas nie brały udziału w protestach, a którym los własnego kraju nie był obojętny. W czasie Rewolucji Ognia protestanci, aby zapewnić sobie bezpieczeństwo i uchronić się od kul snajperów, palili opony. Dym wydobywający się z płonących opon nie pozwalał oddziałom milicji bliżej podejść do protestujących. Były okresy, kiedy opony płonęły przez całą dobę, a czarny dym unosił się wysoko.

Rewolucja efektywności - jest to okres od zakończenia Rewolucji Ognia aż po dziś dzień. Rewolucja ma na celu to, aby za pomocą reform ekonomicznych wprowadzić Ukrainę na europejską drogę rozwoju. Dzisiaj ukraiński rząd i prezydent nie mają prawa 
pomylić się w podjęciu jakichkolwiek decyzji, ponieważ kraj znalazł się w bardzo trudnej sytuacji ekonomicznej, politycznej i społecznej i każda pomyłka może bardzo drogo kosztować. Ukraina wymaga efektywnego przeprowadzenia reform i jeśli one będą udane, to zmiany będą nosić nazwę Rewolucji Efektywności. Aby prezydent i rząd nie popełnili błędów swoich poprzedników, aktywiści zamierzają kontrolować i śledzić każdy krok nowych władz, by hasło kampani prezydenckiej P. Poroszenki, "Żyć po nowemu”, mogło stać się rzeczywistością. Aktywiści zaproponowali, aby te hasło udoskonalić, zmieniając je na „Żyć pod kontrolą", co oznaczałoby, że w razie przeprowadzenia niezbędnych reform, działalność prezydenta, rządu i Rady Najwyższej, podlegałaby kontroli społeczeństwa („Ганна Гопко: Майдан почався як революція гідності, і тепер він має перетворитися в революцію ефективності", b.d.).

\section{UDZIAL KOBIET W REWOLUCYJNYCH WYDARZENIACH}

Bardzo ważną rolę w wydarzeniach na przełomie 2013-2014 roku na Ukrainie odegrały kobiety. Nie tylko wspierały one mężczyzn w walce o lepsze życie, zmiany w społeczeństwie, obalenie bandyckich rządów, ale również same były inicjatorkami wielu bardzo ważnych przedsięwzięć. W niniejszym artykule postaram się wskazać, w jaki sposób brały one udział w Rewolucji Godności i wspierały EuroMajdan.

Ukrainki w trakcie rewolucyjnych wydarzeń wykazały tyle samo odwagi co i mężczyźni. Kiedy rozpoczęła się aktywna faza starć, tzw. Rewolucja Ognia, kobiety pracowały, jako wolontariuszki przy przygotowywaniu posiłków, w szpitalach. Informowały społeczeństwo za pomoca portali społecznościowych o potrzebach rewolucji, pilnowały w szpitalach, aby nie wykradano rannych aktywistów, były aktywnymi uczestniczkami AutoMajdanu². Po krwawych wydarzeniach 18 lutego 2014 roku przywozity opony, drewno, leki, wynosity rannych z linii ognia.

Udział kobiet w rewolucyjnych wydarzeniach można poddać klasyfikacji. Wszystkie kobiety, które brały udział w rewolucji można podzielić na dwie grupy:

- kobiety-aktywistki znane ukraińskiemu społeczeństwu - Rusłana, T. Czornowol, O. Bohomolec, L. Orobec, A. Prychod'ko.

- kobiety-aktywistki pochodzące "z narodu” - studentki, kobiety, starsze kobiety, mieszkanki Kijowa i nie tylko, które brały aktywny udział.

Według innej klasyfikacji, wszystkie kobiety można podzielić na obywatelki Ukrainy i obywatelki innych państw, kochające Ukrainę. Do Ukrainek zaliczamy kobiety wymienione powyżej, w pierwszej klasyfikacji, do nie-Ukrainek można zaliczyć Wiktorię Nuland, Ketrin Ashton, Angelę Merkel, Dalię Gribauskaite. Niektóre z nich odwiedziły Majdan Niepodległości w trudnych dla Ukrainy chwilach i aktywnie działały w swoich kregach politycznych, aby wywrzeć wpływ na władze ukraińskie, a później także rosyjskie.

$\mathrm{Na}$ Plac Niepodległości niektóre kobiety przychodziły tylko na chwilę, inne prawie tam mieszkały. Kobiety różnił nie tylko status społeczny, miejsce zamieszkania, wysokość zarobków, rodzaj wykonywanej pracy, rozponawalnoć lub nierozpoznawalność w społeczenstwie, ale także powody, dla których pojawiły się na Majdanie. Pojawiły się tu kobiety, które wspierały mężów, synów, wnuków. Pojawiły się także kobiety, które przyszły w celu wyrażenia swojego niezadowolenia z istniejącej sytuacji. Były też takie, które

\footnotetext{
-.....

2 Pojęcie wyjaśnione w tekście poniżej.
} 
wspierały Majdan swoją obecnością oraz takie, w których sercach obudził się patriotyzm i duma narodowa. Niezależnie od tego, czy kobiety były szerzej znane w społeczeństwie, czy też nie, ich działania były podobne. Każda z nich starała się pomóc z całych swoich sił i w granicach swoich możliwości. Nie przerażało ich to, że mogły swoje oddanie Ukrainie przypłacić nawet życiem (T. Czornowol).

Poza swoją bezpośrednią obecnością na Majdanie, kobiety realizowały także mnóstwo inicjatyw, aby wesprzeć uczestników Majdanu. Należy wymienić następujące inicjatywy:

- wydanie "Abecadła Majdanu";

- udział w AutoMajdanie;

- powołanie Warty pierwszej pomocy medycznej;

- sformowanie Kobiecej Sotni im. Olgy Kobyliańskiej;

- zorganizowanie "Otwartego Uniwersytetu";

- zorganizowanie Biblioteki Majdanu;

- zorganizowanie incjatywy "EuroMajdan SOS";

- zorganizowanie inicjatywy "Anielska poczta";

- zorganizowanie różnego rodzaju służb wolontariuszy;

- sformowanie pielęgniarskiej sotni Majdanu lub Medycznego Bractwa.

Analizując poszczególne inicjatywy, należy zwrócić uwagę na to, że aby pomóc, kobiety będące poza granicami Ukrainy, w miarę możliwości starały się jakoś wesprzeć rodaków. I tak, na przykład studentka Wyższej Szkoły Sztuki Stosowanej w Paryżu, aby przybliżyć ukraińskie wydarzenia Francuzom w niezniekształconej formie, rozpowszechniała za pomocą grafiki informację w internecie, o tym, jak w rzeczywistości wygląda Ukraina. Nieco później Eugenia Melechowec postanowiła opracować "Abecadlo Majdanu” - przy każdej literze ukraińskiego alfabetu zamieszczała obrazek i słowo, które dotyczyło ukraińskich wydarzeń (rys.1). Abecadło cieszy się popularnością także obecnie, szczególnie u dzieci w wieku przedszkolnym.

Kobiety brały aktywny udział również w AutoMajdanie. Automajdan to zrzeszenie kierowców, które poruszało się w zorganizowanych grupach, a do ich zadań głównie należato: patrolowanie ulic, w celu zapobiegania włamaniom do sklepów, zapobieganie niszczeniu samochodów przez tzw. tituszków (kryminalistów, którzy za pieniądze współpracowali z władzami - brali udział w pobiciach aktywistów, niszczyli witryny sklepów, samochody, na których widniała ukraińska symbolika). Faktycznie AutoMajdan został powołany 1 grudnia 2013 roku i działał w wielu ukraińskich miastach - Kijowie, Doniecku, Łucku, Odessie, Charkowie, Lwowie i innych. Najbardziej głośnymi działaniami AutoMajdanu było blokowanie ruchu samochodowego, wyjazd do rezydencji W. Janukowycza - Meżygirja, polowanie na tituszków („Автомайдан и киевляне начали патрулирование улиц столицы”, b.d.). Bardzo ważną rolę aktywiści AutoMajdanu odegrali przy przewozie rannych aktywistów Majdanu z miejsc starć do szpitali, pełnili także patrole wokół szpitali w celu zapobieżeniu porwaniom aktywistów przez tzw. „szwadrony śmierci”. Założycielem AutoMajdanu był D. Bułatow, który był porwany i katowany przez "szwadrony śmierci" („Автомайдан загнал “титушек» в “Сильпо» и допросил (онлайн)”, b.d.). AutoMajdan nie dzielit się na aktywistów kobiecych i męskich, kobiety na równi z mężczyznami patrolowały ulice oraz, w czasie zaostrzenia się konfliktu, zbierały opony.

Czasem praca kobiet $w$ ramach różnych inicjatyw była podobna. Na przykład, kiedy przypadki porwań ludzi nie tylko ze szpitali zdarzały się coraz częściej, została powołana Warta Pierwszej Pomocy Medycznej. Jak opowiada Anna Saragion, która nie miała wykształcenia medycznego, ale po to, aby pomóc aktywistom Majdanu przychodziła ona do 


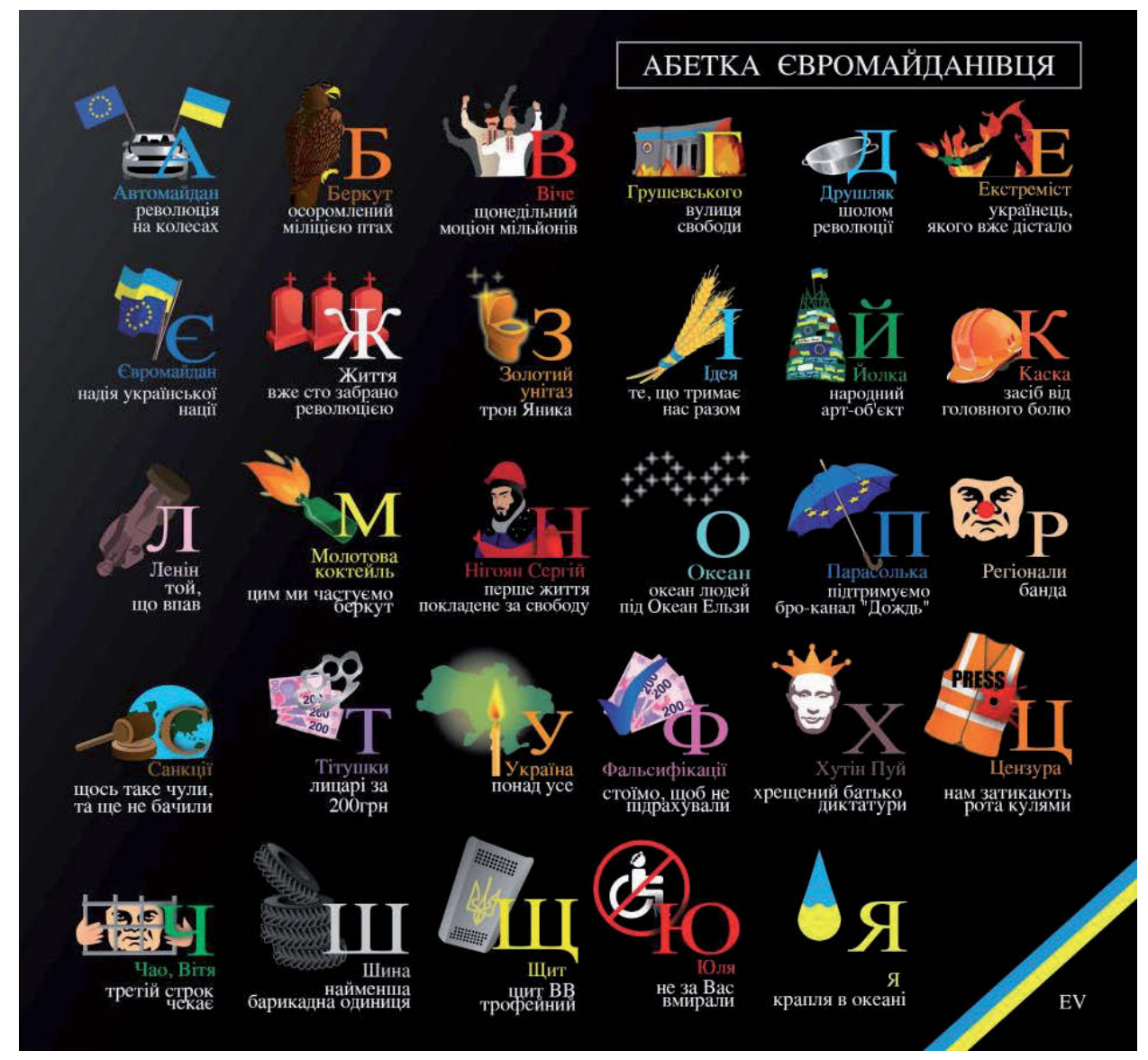

Rys. 1. "Abecadło Majdanu”

Ź r ó dło: В абетці євромайданівця пояснюють значення слів шина, друшляк і золотий унітаз (b.d.), pozyskano z http://tsn.ua/politika/v-abetci-yevromaydanivcya-poyasnyuyut-znachennya-sliv-shinadrushlyak-i-zolotiy-unitaz-338056.html

szpitali, do których przywożono rannych i pod pretekstem, że jest żoną, siostrą (lub przestawiała się fikcyjnym imieniem i nazwiskiem), starała się uzyskać informację o liczbie rannych lub o losach konkretnych osób. Wraz z zaostrzeniem się starć, Warta w szpitałach zaczęła funkcjonować na bieżąco. Kiedy do szpitali przywożono zakrwawionych aktywistów, Anna z kolegami starała się spisywać ich imiona i nazwiska, miejsce zamieszkania, aby zapobiec zniknięciu tych ludzi. Bardzo często aktywiści mieli podartą i zakrwawioną odzież, aktywistki Warty Pierwszej Pomocy Medycznej, przywoziły czyste ubrania oraz żywność. Do osób, które cały czas były pod kontrolą milicji w szpitalu, wstęp był zabroniony, jednak gdy udawało się trafić na lojalnego milicjanta, można było przekazać rannym więźniom jedzenie, za co oni w zamian pisali krótkie liściki z podziękowaniami: "Sława Ukrainie!", "Kochamy Was, dziękujemy za wsparcie” (Майдан. Жіноча справа, 2014, ss. 14-15). 
Na uwage zasługuje Kobieca Sotnia im. Olgy Kobyliańskiej ${ }^{3}$, powołana w odpowiedzi na seksizm, który pojawił się na Majdanie. Celem tej Sotni było pokazać obecność i głos kobiet na Majdanie na równi z męźczyznami. W ramach działalności Kobiecej Sotni organizowano kursy samoobrony dla kobiet oraz wykłady dotyczące praw kobiet, sytuacji kobiet i inne (Майдан. Жіноча справа, 2014, ss. 16-17).

Na Majdanie Niepodległości został powołany także „Uniwersytet pod otwartym niebem". Celem tej inicjatywy było prowadzenie wykładów na różne tematy, m.in. z historii Ukrainy i Kijowa, biznesu, prawa, sztuki. Jedną z lektorek była Maria Dmitriewa, prowadziła ona wykłady temat o historii kobiecego ruchu na Ukrainie, który cieszył się zainteresowaniem nie tylko wielu kobiet, ale również mężczyzn („На Євромайдані працює Відкритий Університет", b.d.).

Władze ukraińskie nie zamierzały rozpoczynać dialogu z manifestującymi i aby jakoś zmienić niewiesołą scenerię tych dni, pojawił się pomysł założenia Biblioteki Majdanu w Ukraińskim Domie („Бібліотека Євромайдану: Етажерки замість баррикад”, b.d.). Została założona strona na Facebooku i do Ukraińskiego Domu zaczęły trafiać pierwsze książki. Zasady funkcjonowania Biblioteki z szybko rozrastającym się księgozbiorem były proste - ludzie przychodzili i brali książki, za obietnicę zwrotu, ci którzy je zwracali dostawali cukierka. W księgozbiorze były książki o tematyce psychologicznej, filozoficznej. Poza nimi można tam było znaleźć również kryminały, romansy i inne. Książki przynoszono o każdej porze dnia. W bardzo krótkim czasie w księgozbiorze Biblioteki Majdanu znalazło się ponad 3000 książek („У бібліотеці Євромайдану уже $є$ понад три тисячі книг”, b.d.).

Bardzo ważne znaczenie miała inicjatywa EuroMajdan SOS, dobrowolne zrzeszenie prawników, dziennikarzy, aktywistów i innych zainteresowanych pomocą osób wykonujących różne zawody, które powstało w odpowiedzi na bezprawne działania rządu mające na celu pacyfikacje manifestów w nocy z 29 na 30 listopada 2013 roku na Placu Niepodległości. Celem EuroMajdanu SOS było zapewnienie pomocy prawnej ofiarom EuroMajadanu, a także zbieranie i analizowanie informacji w celu ochrony praw demonstrantów („Євромайдан SOS”, b.d.). Swoją pracę grupa EuroMajdan SOS rozpoczęła tuż przed pierwszą próbą pacyfikacji pokojowych protestów, czyli 30 listopada. Grupa udzielała porad za darmo, calodobowo, na zasadach samooganizacji, solidarności i odpowiedzialności. Do głównych kategorii porad, jakie były udzielane, należały informacje na temat dochodzenia swoich praw w przypadku wystąpienia uszkodzenia ciała na skutek działań odziałów milicji mających na celu ograniczenie ich konstytucyjnego prawa do wolności i pokojowych zgromadzeń; nielegalnego przetrzymywania członków pokojowych zgromadzeń, także porad mających na celu ochronę praw uczestników pokojowych zgromadzeń w przypadku wszczęcia przeciwko nim postępowań administracyjnych lub karnych. Grupa poszukiwała także zaginionych uczestników pokojowych zgromadzeń po pacyfikacji ich przez odziały milicji „Berkut” („євромайдан-SOS продовжує шукати людей”, b.d.). Јeј działalność polegała też na zapobieganiu wywierania nacisków na studentów ze strony uniwersytetów, aby nie brali oni udziału w manifestacjach oraz zapobieganiu zastraszeniu i przeszkadzaniu im w dojeździe do głównego miejsca zdarzeń, czyli na Plac Niepodległości („Євромайдан-SOS продовжує шукати людей”, b.d.).

$W$ ramach tej inicjatywy kobiety pracowały jako pomoc psychologiczna. Pomagały rodzinom szukać zaginionych uczęstników Majdanu. Kiedy padły pierwsze ofiary starć, rozpoczęły obliczanie ofiar, zawiadamiały rodziny, dla rannych szukały pomocy za granicą.

\footnotetext{
$\cdots \cdots$

3 Pojęcie wyjaśnione w tekście poniżej.
} 
Na przybliżenie zasługuje także inicjatywa "Anielska poczta”, akcja zorganizowana przez kobiety. Na początku miała ona na celu udzielanie wsparcia, podnoszenie na duchu, poprawę dobrego nastroju, utrzymanie dialogu pomiędzy samymi uczestnikami Majdanu. Aktywistki przebrane za anioły rozdawały karteczki z różnymi hasłami, słowami wsparcia, które miały również wpłynąć na poprawę samopoczucia. Po krwawych zdarzeniach, które rozegrały się na ul. Hruszewskiego i pierwszych ofiarach śmiertelnych wśród protestujących, kobiety przebrane za anioły szły w stronę oddziałów milicji „Berkut”, z apelem, aby nie strzelano do bezbronnych ludzi. Zachęcały one również odziały milicji do wspólnej „Modlitwy za Ukrainę" i zastanowienia się nad tym, czy są po właściwej stronie. Jednak nie udało się im nawiązać dialogu z siłami bezpieczeństwa („Активістка: «Жінки часто ставали тими, хто стримував збройне протистояння»", b.d.).

Na uwagę zasługują działania poszczególnych kobiet. Na przykład, ukraińska piosenkarka Rusłana była od pierwszych dni protestów na Majdanie. Zachęcała ludzi do tego, aby trzymali się razem, nie tracili ducha. Piosenkarka wiele czasu spędzała razem z protestującymi. Podróżując po Europie, starała się przekazywać informacje o wydarzeniach, które rozgrywały się na Ukrainie, aby nakłonić przywódców rządów europejskich do wsparcia Ukrainy. Rusłana uzyskała nagrodę na rzecz Międzynarodowego Dnia Odwagi Kobiet, która została jej wręczona w USA („Руслана визнана найсміливішою жінкою світу за активність на Майдані", b.d.). Drugą osobą wartą uwagi jest O. Bohomolec, która w czasie krwawych starć na Majdanie udzielała pierwszej pomocy rannym. Po zakończeniu wydarzeń, aktywność O. Bohomolec nie zmalała, mimo aktywnego udziału w procesie wyborczym (była kandydatem na stanowisko prezydenta). O. Bohomolec w dalszym ciągu bierze udział w działalności Medycznej Sotni Majdanu (zrzesza nie tylko kobiety, ale również męźczyzn), udzielając pomocy w zbieraniu medykamentów dla szpitali na wschodzie Ukrainy. Wolontariusze budują bazę danych wszystkich lekarzy, którzy byli obecni na Majdanie i udzielali pomocy w różnych punktach, takich jak Cerkiew Michajłowska, hotel „Ukraina”, Budynek Związków Zawodowych (Богомолець, b.d.). Wolontariusze Medycznego Bractwa zbierali i zbierają dokumenty, aby pomóc rannym na Majdanie, którzy potrzebują badań kontrolnych lub dodatkowego leczenia za granicą. Wolontarusze zalatwiają dokumentację niezbędną dla uzyskania możliwości leczenia w Polsce, na Łotwie, w Czechach, Izraelu, Niemczech. Bardzo często też organizują zbiórkę pieniędzy na pokrycie kosztów leczenia i przelot.

\section{WNIOSKI}

Ukraińskie kobiety odegrały istotną rolę w wydarzeniach na przełomie 2013-2014 roku. Udowodniły, że mogą walczyć o lepszą przyszłość na równi z mężczyznami. W czasie trwania Rewolucji Godności nie tylko gotowały i roznosiły jedzenie, ale przygotowywały i przynosiły „koktaile Mołotowa”, rozbierały i kruszyły kostkę brukową. Były aktywnymi uczestniczkami AutoMajdanu, na równi z mężczyznami patrolowały dzielnice Kijowa. Kobiety ramię $w$ ramię stały z mężczyznami na 20-stopniowym mrozie i walczyły o swoją przyszłość i o przyszłość narodu ukraińskiego. Pracowały jako tłumaczki, organizatorki różnych inicjatyw, jako lekarze, psycholodzy, dziennikarze.. Wiele kobiet zaczęło intensywniej działać społecznie, organizując różnorakie inicjatywy albo przyłączając się do już istniejących. 
Bardzo często ukraińska kobieta jest nazywana Berehynią, utożsamianą z opiekunką rodziny, domu, narodu lub państwa. Jest to kobieta nieustraszona, która $w$ razie niebezpieczeństwa ochroni dom, rodzinę, kraj. W rewolucyjnych wydarzeniach Ukrainki pokazały światu, że są prawdziwymi Berehyniami ukraińskiego narodu.

\section{BIBLIOGRAFIA}

Godność. (2014, czerwiec 30). W Słownik języka polskiego. Pobrano z http://sjp.pwn.pl/ haslo.php?id=2462219

Konstytucja Rzeczypospolitej Polskiej z dnia 2 kwietnia 1997 r. uchwalona przez Zgromadzenie Narodowe w dniu 2 kwietnia 1997 r., przyjęta przez Naród w referendum konstytucyjnym w dniu 25 maja 1997 r., podpisana przez Prezydenta Rzeczypospolitej Polskiej w dniu 16 lipca 1997 r. (1997). Dz.U. 1997 nr 78 poz. 483, z późn. zm.

Ukraina: "dyktatorskie ustawy" ekspresowo wchodzą w życie. (b.d.). Pobrano 21 stycznia 2014, z http://www.polskieradio.pl/5/3/Artykul/1029574,Ukraina-dyktatorskie-ustawyekspresowo-wchodza-w-zycie

Wartości europejskie. (b.d.). Pobrano 30 czerwca 2014, z http://www.bbc.co.uk/polish/ specials/1942_european_values/

Автомайдан загнал „титушек” в „Сильпо” и допросил (онлайн). (b.d.). Pobrano 21 stycznia 2014, z http://gazeta.ua/ru/articles/np/_avtomajdan-zagnal-titushek-v-silpo-i-doprosilonlajn/537383

Автомайдан и киевляне начали патрулирование улиц столицы. (b.d.). Pobrano 21 stycznia 2014, z http://news.liga.net/news/politics/963989-v_stolitse_avtomaydan_i_kievlyane_nachali_patrulirovanie_ulits.htm

Активістка: „Жінки часто ставали тими, хто стримував збройне протистояння". (b.d.). Pobrano 30 czerwca 2014, z http://gurt.org.ua/interviews/21330/

Бібліотека Євромайдану: Етажерки замість баррикад. (b.d.). Pobrano 31 stycznia 2014, z http://life.pravda.com.ua/culture/2014/01/31/150643/

Богомолець, O. (b.d.). Наша держава показала неспроможність захищати свій народ і цілісність території... Pobrano 21 marca 2014, z http://www.socportal.info/news/pravozahisnik-vidznachat-nayaktivnishih-zhinok-maydanu

В абетці євромайданівця пояснюють значення слів шина, друшляк і золотий унітаз. (b.d.). Pobrano 4 marzec 2014, z http://tsn.ua/politika/v-abetci-yevromaydanivcya-poyasnyuyut-znachennya-sliv-shina-drushlyak-i-zolotiy-unitaz-338056.html

Ганна Гопко: Майдан почався як революція гідності, і тепер він має перетворитися в революцію ефективності. (b.d.). Pobrano 30 czerwca 2014, z http://uacrisis.org/ua/ hanna-hopko/

Гундорова, Т. (2001). Ольга Кобилянська contra Ніцше, або Народження жінки з духу природи. W Гендер і культура. Збірник статей (ss. 34-52). Київ: видавництво Факт.

Євромайдан SOS. (b.d.). Pobrano 30 czerwca 2014, z http://euromaidansos.org/uk/ node/20

Євромайдан-SOS продовжує шукати людей. (b.d.). Pobrano 25 lutego 2014, z http:// www.pravda.com.ua/news/2014/02/25/7016219/

Конституція України. (1996). Відомості Верховної Ради України (ВВР), № 30, ст. 141, із змінами. 
Майдан. Жіноча справа. (2014). Київ: Український жіночий фонд.

На Євромайдані працює Відкритий Університет. (b.d.). Pobrano 17 grudnia 2013, z http:// ridna.ua/2013/12/na-evromajdani-pratsyuje-vidkrytyj-universytet/

Революція гідності: ми маємо пам'ятати. (b.d.). Pobrano 4 kwietnia 2014, z http://life.pravda.com.ua/columns/2014/04/4/161603/

Руслана визнана найсміливішою жінкою світу за активність на Майдані. (b.d.). Pobrano 30 czerwca 2014, z http://artnews.in.ua/news/ukraine/1711-ruslana-viznana-naysmlivshoyu-zhnkoyu-svtu.html -

Сутички після Народного Віча у Києві. (b.d.). Pobrano 19 stycznia 2014, z http://www. bbc.co.uk/ukrainian/multimedia/2014/01/140119_kyiv_clashes_gallery.shtml

у бібліотеці Євромайдану уже є понад три тисячі книг. (b.d.). Pobrano 6 lutego 2014, z http://radio24.ua/news/showSingleNews.do?objectld=13195

\section{BIBLIOGRAPHY}

Aktyvistka: "ZHinky chasto stavaly tymy, khto strymuvav zbroinne protystoiannia». (n.d.). Retrieved June 30, 2014, from http://gurt.org.ua/interviews/21330/

Avtomaĭdan i kievliane nachali patrulirovanie ulits stolitsy. (n.d.). Retrieved January 21, 2014, from http://news.liga.net/news/politics/963989-v_stolitse_avtomaydan_i_kievlyane_nachali_patrulirovanie_ulits.htm

Avtomaĩdan zagnal "titushek" v "Sil'po" i doprosil (onlaĭn). (n.d.). Retrieved January 21, 2014, from http://gazeta.ua/ru/articles/np/_avtomajdan-zagnal-titushek-v-silpo-i-doprosil -onlajn/537383

Biblioteka IEvromaĭdanu: Etazherky zamist' barrykad. (n.d.). Retrieved January 31, 2014, from http://life.pravda.com.ua/culture/2014/01/31/150643/

Bohomolets', O. (n.d.). Nasha derzhava pokazala nespromozhnist' zakhishchaty sviĭ narod i tsilisnist' terytoriï... Retrieved March 21, 2014, from http://www.socportal.info/news/ pravozahisnik-vidznachat-nayaktivnishih-zhinok-maydanu

Godność. (2014, June 30). In Słownik języka polskiego. Retrieved from http://sjp.pwn.pl/ haslo.php?id=2462219

Hanna Hopko: Maĭdan pochavsia iak revoliutsiia hidnosti, i teper vin maie peretvorytysia $\checkmark$ revoliutsiiu efektyvnosti. (n.d.). Retrieved June 30, 2014, from http://uacrisis.org/ua/ hanna-hopko/

Hundorova, T. (2001). Ol'ha Kobylians'ka contra Nitsshe, abo Narodzhennia zhinky z dukhu pryrody. In Gender i kul'tura. Zbirnyk statei (pp. 34-52). Kyïv: vydavnytstvo Fakt.

IEvromaĭdan SOS. (n.d.). Retrieved June 30, 2014, from http://euromaidansos.org/uk/ node/20

IEvromaĭdan-SOS prodovzhuie shukaty liudeľ. (n.d.). Retrieved February 25, 2014, from http://www.pravda.com.ua/news/2014/02/25/7016219/

Konstytucja Rzeczypospolitej Polskiej z dnia 2 kwietnia 1997 r. uchwalona przez Zgromadzenie Narodowe w dniu 2 kwietnia 1997 r., przyjęta przez Naród w referendum konstytucyjnym w dniu 25 maja 1997 r., podpisana przez Prezydenta Rzeczypospolitej Polskiej w dniu 16 lipca 1997 r. (1997). Dz.U. 1997 nr 78 poz. 483, z późn. zm. 
Konstytutsiia Ukraïny. (1996). Vidomosti Verkhovnoï Rady Ukraïny (VVR), № 30, st. 141, iz zminamy.

Maìdan. Zhinocha sprava. (2014). Kyïv: Ukraïns'kyĭ zhinochy̆ fond.

$\mathrm{Na}$ IEvromaĭdani pratsiuie Vidkrytyĭ Universytet. (n.d.). Retrieved December 17, 2013, from http://ridna.ua/2013/12/na-evromajdani-pratsyuje-vidkrytyj-universytet/

Revoliutsiia hidnosti: my maiemo pam'iataty. (n.d.). Retrieved April 4, 2014, from http:// life.pravda.com.ua/columns/2014/04/4/161603/

Ruslana vyznana naǐsmilyvishoiu zhinkoiu svitu za aktyvnist' na Maĭdani. (n.d.). Retrieved June 30, 2014, from http://artnews.in.ua/news/ukraine/1711-ruslana-viznana-naysmlivshoyu-zhnkoyu-svtu.html -

Sutychky pislia Narodnoho Vicha u Kyievi. (n.d.). Retrieved January 19, 2014, from http:// www.bbc.co.uk/ukrainian/multimedia/2014/01/140119_kyiv_clashes_gallery.shtml

U bibliotetsi IEvromaĭdau uzhe ie ponad try tysiachi knih. (n.d.). Retrieved February 6, 2014, from http://radio24.ua/news/showSingleNews.do?objectld=13195

Ukraina: "dyktatorskie ustawy" ekspresowo wchodzą w życie. (n.d.). Retrieved January 21, 2014, from http://www.polskieradio.pl/5/3/Artykul/1029574,Ukraina-dyktatorskieustawy-ekspresowo-wchodza-w-zycie

$\checkmark$ abettsi ievromaĩdanivtsia poiasniuiut' znachennia sliv shyna, drushliak i zoloty̆ unitaz. (n.d.). Retrieved March 4, 2014, from http://tsn.ua/politika/v-abetci-yevromaydanivcyapoyasnyuyut-znachennya-sliv-shina-drushlyak-i-zolotiy-unitaz-338056.html

Wartości europejskie. (n.d.). Retrieved June 30, 2014, from http://www.bbc.co.uk/polish/ specials/1942_european_values/ 